\title{
Increasing social responsibility in tourism based on volunteer tourism
}

\author{
Iryna Trunina ${ }^{1}$, Inna Khovrak $^{2 *}$ and Maryna Bilyk $^{1}$ \\ ${ }^{1}$ Kremenchuk Mykhailo Ostrohradskyi National University, Tourism Department, 39600 \\ Kremenchuk, Ukraine \\ ${ }^{2}$ Kremenchuk Mykhailo Ostrohradskyi National University, Accounting and Finance Department, \\ 39600 Kremenchuk, Ukraine
}

\begin{abstract}
The aim of the paper is to determine the impact of volunteer tourism on the level of social responsibility in the tourism industry of Ukraine. The online survey included 440 respondents $(77.3 \%$ women; $22.7 \%$ men). Physicians were asked about the importance of volunteering and their participation in the volunteer movement. According to the results of the survey, $59.1 \%$ of respondents do not have volunteering experience, $38.6 \%$ of respondents have episodic experience and only $2.3 \%$ of respondents constantly participate in volunteer activity. Although a quarter of respondents who do not have volunteering experience do not consider it appropriate to have such experience. This allowed us to identify the motives for engagement in volunteering and the factors hindering such activities. Participants were also asked about the impact of volunteer tourism on the prosperity of regional communities, building a democratic society, education of socially responsible citizens. The research has shown that for the development of volunteer tourism the most important is the promotion of volunteerism in society $(61.4 \%$ of respondents) and cooperation with international organizations $(50.0 \%)$. This allowed the authors to suggest directions and forms of international cooperation for the development of volunteer activities in the tourism.
\end{abstract}

\section{Introduction}

In recent years, the ideas and principles of socially responsible tourism as a world-wide conceptual tendency of mass recreation of citizens have been becoming popular in the world. This combination of pleasure travels to any unique place with the opportunity to visit its attractions and provide socially useful assistance to the benefit of the region. To streamline these processes, the Cape Town Declaration on Responsible Tourism was adopted in 2002 and its principles were formally approved. In June 2016, the concept of socially responsible tourism was presented at the 12th International Conference on Responsible Tourism in Finland.

\footnotetext{
*Corresponding author: inna.khovrak@gmail.com
} 
There are the following types of responsible tourism: (1) Ecological (contributes to the protection of the environment and the maintenance of the welfare of the local population, different from natural tourism with the presence of commitments in relation to environmental protection and the development of regions). (2) Volunteer (carries out volunteer missions in support of responsible tourism, especially in the objects and territories studied by scientists or other specialists). (3) Religious (combines religious values with the natural, cultural, historical heritage of the region and contributes to making a work contributes to improving the lives of churches and monasteries). It is worth pointing out that the ecological and religious aspects of responsible tourism are well-known and common in Ukraine. However, the phenomenon of volunteer tourism in Ukraine is rather new and little known. At the same time, at the present stage of development of the society, the volunteer institute is a widespread phenomenon in many countries. Moreover, the work of volunteers with each passing year becomes an increasingly significant resource for the development of the world economy, in particular, the tourism industry. Participation in the volunteer movement benefits both society as a whole and the volunteer itself. Attracting people into volunteer activity is one of the important indicators of the level of selforganization of society. Volunteerism creates opportunities for socially active young people to realize their potential, to help others, to find support and to feel the social value of their work, to obtain certain life skills, and so on.

That is why the purpose of the study is to determine the impact of volunteer tourism on the level of social responsibility in the tourism industry in Ukraine. The research was carried out in the following sequence: the essence and characteristics of voluntarism were determined, an evaluation of the potential of voluntarism in Ukraine was outlined, prospects of international cooperation for the development of volunteering activities in the tourism sector were outlined.

\section{Data and Methods}

The online survey among 440 respondents $(77.3 \%$ or 340 people are women; $22.7 \%$ or 100 people are men). Distribution of respondents by age under 18 years old $(2.3 \%), 18-25$ years (63.6\%), 26-35 years $(22.7 \%), 36-50$ years $(9.1 \%)$, over 50 years $(2.3 \%)$. The survey was opened online on May 1, 2019, and closed on May 19, 2019. Each participant could complete the questionnaire only once. All of the participants were asked about their age and gender. Physicians were asked about the importance of volunteering and their participation in the volunteer movement. Participants were also asked about the impact of volunteer tourism on the prosperity of regional communities, building a democratic society, education of socially responsible citizens. This allowed us to identify the motives for engagement in volunteering and the factors hindering such activities. The authors proposed directions and forms of international cooperation for the development of volunteering in the tourism.

\section{Results}

\subsection{The Essence and Characteristics of Volunteer Tourism}

Volunteer tourism is based on the sustainable development of the tourism industry in the long run and the support of the socially weak sections of society in countries where tourism is extremely productive. One of the priorities of the concept of volunteering is to support the cultural exchange between tourists and the local population, taking into account the identity of each nationality, and a reasonable redistribution of income from tourism. A significant innovation in the strategy of volunteer tourism is the reduction of costs and excessive consumption, which will positively affect ecological equilibrium. In volunteer 
tourism, the desire for profit is inferior to the more altruistic desire to travel in order to help communities. So the predominance of altruistic motives over commercial volunteer tourism is primarily an alternative to mass tourism. Table 1 shows the main characteristics of volunteer tourism.

Table 1. The main characteristics of volunteer tourism

\begin{tabular}{|l|c|c|c|c|c|c|c|}
\hline & {$[6]$} & {$[7]$} & {$[8]$} & {$[9]$} & {$[10]$} & {$[11]$} & {$[12]$} \\
\hline help for certain social groups & + & + & + & + & & & \\
\hline individuals travelling on a nonpaid working holiday for worthy causes & & + & & & & & \\
\hline participating in a variety of social, educational and environmental projects & & & + & + & + & & \\
\hline does not focus on profits & & & & + & & & \\
\hline a short-term trip, less than three months & & & & & + & & \\
\hline yet another form of post-colonialism and globalization & & & & & & + & \\
\hline responsible tourism & & & & + & & & \\
\hline counteraction to corporate burnout & & & & & & & + \\
\hline
\end{tabular}

Volunteer tourism is a form of tourism that involves voluntary assistance for certain social groups, participation in social projects of different orientations, not focusing on profit, but on sustainable development of regions. Volunteer tourism has some advantages over other types of tourism: (1) Attracting a significant number of tourists by creating volunteer tours in the region; (2) Volunteer tourism does not limit volunteers to the choice of season; (3) If the event is long-term, the time of stay of volunteer tourists is increasing; (4) Volunteering tours are usually for different age groups; (5) This type of tourism does not require presence on the territory of natural resources. One of the most learned components of volunteer activity is motivation. The volunteer activity represents a unique opportunity for man to combine the satisfaction of his personal needs with the needs of society. World experience proves that the formation of the motivation plays an important role in the environment, especially educational [13-18]. In addition, there are a number of specific barriers caused by the natural fears and risks of the individual, in connection with the unrelatedness and danger of volunteer tourism. That is why it is relevant to identify the most promising directions of cooperation between Ukraine and other countries in terms of volunteer activity. In addition to countries, international cooperation actors also include domestic and foreign volunteer organizations, non-governmental organizations, higher educational institutions, etc.

\subsection{Estimation of Volunteer Tourism in Ukraine}

According to the results of the survey, $59.1 \%$ of respondents do not have volunteering experience, $38.6 \%$ of respondents have episodic experience and only $2.3 \%$ of respondents constantly participate in volunteer activity. It is important that none of the respondents chose the answer "do not consider it necessary to have such experience". However, answering questions about the frequency of volunteering, $13.6 \%$ of respondents indicated that they did not consider it appropriate to engage in volunteering. That is, from $59.1 \%$ of respondents who do not have experience in such activity, practically a quarter does not consider it appropriate to have such experience. In this case, $13.6 \%$ of respondents consider it necessary to engage in volunteering once a week and more often, $50 \%-1-2$ times a month, 13.6\% - 1-2 times a half year, 9.1\% - 1-2 times a year and less often.

Among the reasons that most impede engagement with volunteering, the respondents preferred the lack of information about volunteer organizations and initiatives $(34.1 \%$ of respondents), lack of time (31.8\%), and lack of confidence in volunteer organizations $(18.2 \%)$. Also, the reasons for low activity in volunteering are the presence of own problems $(9.1 \%$ of respondents), lack of self-confidence / knowledge / experience $(4.5 \%)$ and lack of willingness to engage in volunteer activities $(2.3 \%)$. 
Mostly, the volunteer activity of respondents was participation in community projects and fundraising for patients, helping vulnerable people and animals, distributing information and more. The survey found that respondents considered the following areas of volunteering to be the most necessary in Ukraine: assistance to children $(63.6 \%$ of respondents chose this sphere as one of the 5 most important ones), assistance to people with special needs (59.1\%), homeless animals (56.8\%), urban improvement and community development $(50.0 \%)$, assistance to the elderly $(50.0 \%)$. For the development of the volunteer movement, it is necessary to understand the motives that can bring the population to volunteer activity. Respondents were asked to select a maximum of five out of fourteen options. The most popular were motives like helping others (56.8\% of respondents), feeling their own need $(40.9 \%)$, acquiring professional skills $(40.9 \%)$ and gaining new knowledge $(40.9 \%)$. The least motivation for volunteering is to follow the example of friends / relatives / colleagues (only $6.8 \%$ of respondents chose this answer). According to respondents, the main qualities of volunteers are the desire to help solve the problem $(72.7 \%$ of respondents believe), responsibility $(70.5 \%)$, selflessness $(61.4 \%)$, kindness (47.7\%) and communication skills (45.5\%).

Absolutely all respondents indicated that they love to travel. At the same time, $40.9 \%$ of respondents indicated that they would like to try themselves volunteers abroad in their lifetime. In this case, $9.1 \%$ of respondents do not plan to receive such experience, and $50 \%$ have not yet been determined. One of the reasons for this situation is the lack of awareness of the population about the opportunities and benefits of volunteering, as well as the lack of knowledge about the existence of volunteer programs, projects or organizations. Thus, $65.9 \%$ of respondents did not hear about the existence of international volunteer programs, projects or organizations, $13.6 \%$ - have the positive experience of cooperation, $13.6 \%$ plan to join international programs. However, $6.9 \%$ of respondents know, but do not use the possibilities of international cooperation in the field of volunteering. It was found that volunteer activity has the greatest impact on the education of socially responsible citizens (38.6\% of respondents recognized the maximum impact of volunteering on this factor). According to respondents, the significant influence of volunteer activity is possible on the construction of a democratic society, as well as on the well-being and prosperity of regional communities. In order to accelerate the development of voluntarism, the most important is the promotion of volunteerism in society $(61.4 \%$ of respondents) and cooperation with international organizations $(50.0 \%)$. According to respondents, the least impact is the consolidation of the efforts of civic organizations $(2.3 \%)$.

\subsection{The prospects of international cooperation for the development of voluntary activities in the tourism sector}

As the research showed, one of the most effective areas of cooperation today is the development of joint international social projects, with the involvement of volunteers. The second area of cooperation is the organization of cooperation at the expert level. The third area of cooperation is raising awareness of the Ukrainian population about the development of volunteer activities, volunteer projects and programs (Fig. 1).

\section{Conclusion}

Socially responsible tourism is a set of measures, recommendations and rules for travelers and providers of tourist services that promotes sustainable development of the regions. It applies to any type of tourism and encourages all tourists to contribute to the development of territories, to help local communities, to have an active civic position. Accordingly, tourists are able to travel consciously and be attracted to the life of that small, original world, where they travel. Socially responsible tourism can be internal (when representatives 
of the tourism industry, in addition to profit, are aimed at socio-cultural, ecological and economic transformation of the society within the region of residence) and external (when representatives of the tourism industry, in addition to profit, are aimed at socio-cultural, ecological and economic transformation of the society within the regions of temporary stay).

Objective: formation of economic, organizational and legal conditions for the development of international volunteering

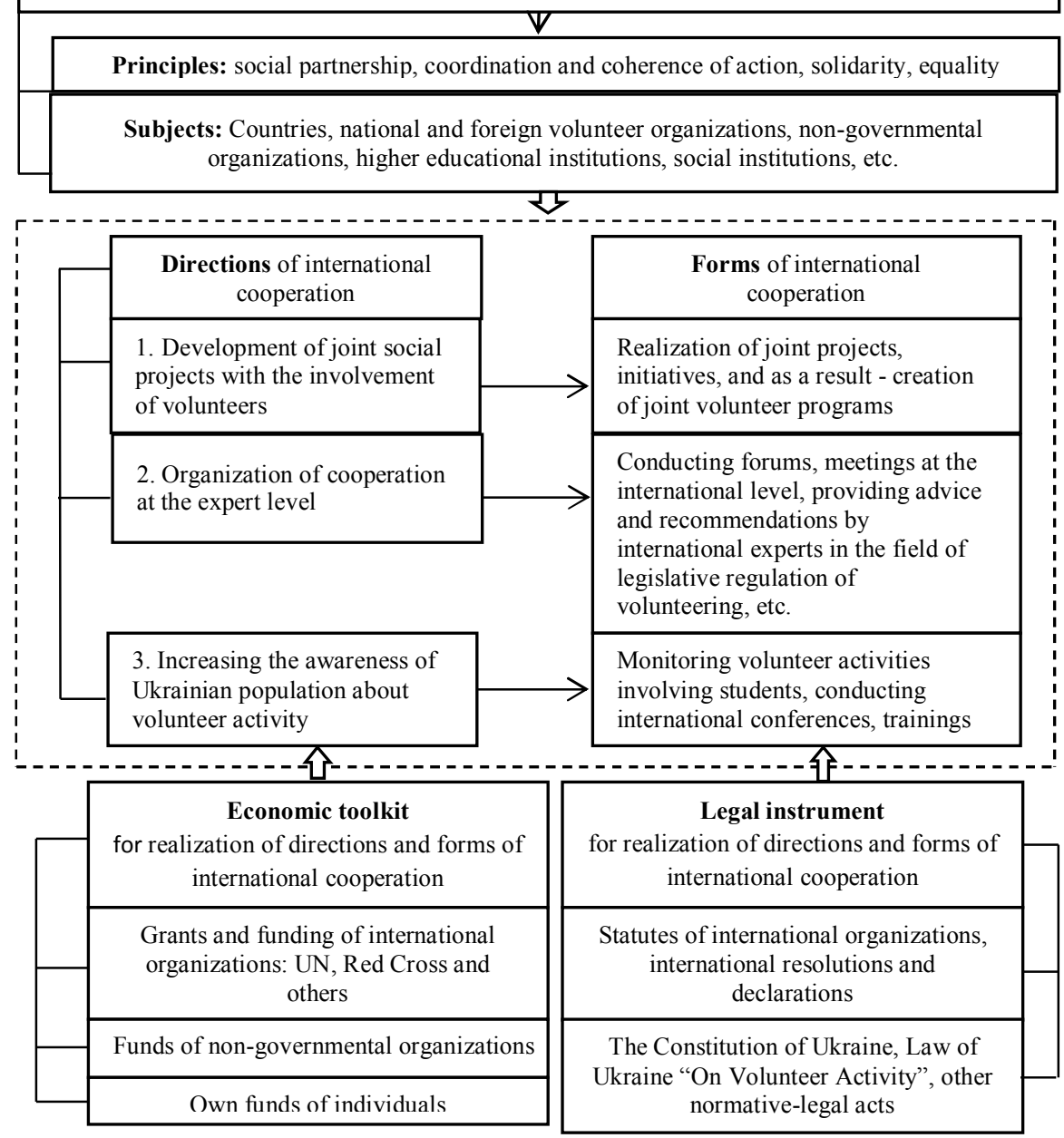

Fig. 1. Scheme of realization of directions and forms of international cooperation for the development of volunteer activity* source: own research

A socially responsible tourist is a person who supports objects and initiatives of socially responsible tourism, adheres to the rules and principles of responsible tourism in travel and in life. The tourist voluntarily participates in projects of socially responsible tourism, independently determines its conditions, or accepts the terms of the project. Participation of a tourist may be non-material (socially useful labour) or material (fully or partially covers the cost of the tour, taking part in volunteer activities based on charitable or membership fees). Stakeholders of responsible tourism are (1) authorities (state, regional and municipal levels) in the field of tourism and in other related fields (sports and youth policy, ecology, industry, economy, culture, investments); (2) business (all interested representatives carrying out socially responsible actions and supporting projects of responsible tourism); 
(3) non-profit sector and especially funds that lead the direction of responsible tourism; (4) higher educational establishments (especially those who specialize in tourism); (5) tourists who travel consciously. The study found that $59.1 \%$ of respondents do not have volunteering experience, $38.6 \%$ of respondents have episodic experience and only $2.3 \%$ of respondents constantly participate in volunteer activity. Although, a quarter of respondents who do not have experience in volunteering does not consider it appropriate to have such experience. However, respondents believe that volunteer tourism has a significant impact on the prosperity of regional communities, building a democratic society, education of socially responsible citizens. Therefore, in order to make volunteer tourism a priority for tourism development, it is necessary to outline the benefits of volunteer tourism, as well as actualize the motives of people in the voluntary sphere. Understanding the motivations of volunteers is a key skill for good leaders of volunteer programs in tourism. This is a prerequisite for helping tourists to realize their motivation and prevent cases where motivation can cause certain complications. An important aspect of volunteering development for Ukraine is the formation of international cooperation in this field.

\section{References}

1. Wearing S. Volunteer Tourism: Experiences That Make a Difference. New York: CABI (2001)

2. Cheung S., Michel M., Miller D. Voluntourism: Give a Little, Gain a Lot. Ontario: Georgian College Research Analyst Program. [online]. Available at: https://voluntourismgal.files.wordpress.com/ (2010)

3. Benson, A. (ed.) Volunteer Tourism: Theory Framework to Practical Applications. New York: Routledge (2011)

4. Carter K. Volunteer Tourism: An Exploration of the Perceptions and Experiences of Volunteer Tourists and the Role of Authenticity in Those Experiences. [online]. Available at: https://researcharchive.lincoln.ac.nz/ (2008)

5. Daldeniz, Bilge and Hampton, Mark P. VOLUNtourists versus volunTOURISTS: a true dichotomy or merely a differing perception? In: Benson, Angela M., ed. Volunteer Tourism: Theory Framework to Practical Applications. Routledge (2010)

6. McGehee, N. G., \& Andereck, K. Volunteer tourism and the "voluntoured": The case of Tijuana, Mexico. Journal of Sustainable Tourism, 17(1), 39-51 (2009)

7. Brown, Sally A. Voluntourism - Traveling with a Purpose: Understanding the Motives and Benefits. Ph.D. diss., Purdue University, West Lafayette, Ind. (2005)

8. Kratt O. Trunina I., Zagirniak D. The assessment of the provision of the industry by electrical engineers. International Conference on Modern Electrical and Energy System (MEES). P. 356-359 (2017)

9. Buzko I., Vartanova O., Trunina I., Khovrak I. Theoretical aspects of regional sustainable development in the EU and Ukraine. SHS Web of Conferences. Volume 61, 01001 (2019)

10. Sushchenko O., Trunina I., Klok O., Loseva O. Management technologies of ensuring environmental protection as the territory development strategic priority. SHS Web of Conferences. Volume 61, 01026 (2019)

11. Trunina I., Kushal I., Zagirniak D. An imitation model of financial-economic mechanism of taking strategic decisions at the enterprise. SHS Web of Conferences. Volume 61, 01027 (2019)

12. Zagirniak D., Khovrak I., Perevozniuk V. The Convergence of the Systems of Education at Scottish and Ukrainian Universities in the Context of Ethic Leadership. International Journal of Engineering \& Technology, Vol 7, № 4.3, Special Issue 3. P.: 550-556 (2018)

13. Kratt O., Pryakhina K., Bilyk M. Ukrainian-Chinese collaboration: Prospects of development. SHS Web of Conferences. EDP Sciences, 39, 01014 (2017) 